\title{
Serum IgG antibodies in patients with cystic fibrosis with early Pseudomonas aeruginosa infection
}

\author{
M M BRETT, A T M GHONEIM, AND J M LITTLEWOOD \\ Departments of Medicine, Microbiology, and Paediatrics, St James's University Hospital, Leeds
}

SUmmary Serum IgG antibodies to Pseudomonas aeruginosa surface antigens were measured by enzyme linked immunosorbent assay in all patients with cystic fibrosis from whom $P$. aeruginosa was isolated for the first time during a study period of 18 months. In 15 patients the titre of serum IgG antibodies was greater than control values before or at the time of the first bacteriological isolation of $P$. aeruginosa. The presence of serum antibodies specific to $P$. aeruginosa suggests exposure to infection by that organism for some months before its isolation in significant numbers from the respiratory tract. In the other two patients serum titres were within the control range before isolation of $P$. aeruginosa but had increased to above the control range within the next month. Longitudinal studies on the entire group of patients showed further increases in titre concurrently with further isolations of $P$. aeruginosa. These results suggest that this assay may be an indicator of the beginning of pulmonary infection by $P$. aeruginosa and may prove to be a sensitive monitor of the progress of infection, and response to treatment, during the first months of infection by that organism.

Pulmonary infection by Pseudomonas aeruginosa remains a major cause of morbidity and mortality in patients with cystic fibrosis. Indeed, once $P$. aeruginosa is well established in the lungs it is rarely, if ever, completely eradicated, despite aggressive antipseudomonal chemotherapy. ${ }^{12}$ In the early stages of pulmonary infection patients produce little or no sputum and bacteriological examination of the respiratory tract is commonly based on throat swabs. Even if sputum is produced, organisms that are present in low numbers are difficult to evaluate by available bacteriological techniques, and their significance may be in doubt. There is a need for a test to detect the presence of $P$. aeruginosa and to monitor the progress of the early stages of infection by that organism.

We have previously described an enzyme linked immunosorbent assay (ELISA) that measured free serum IgG antibodies against $P$. aeruginosa cell surface antigens. This was shown to be a specific and sensitive monitor of the progress of infection in patients with cystic fibrosis from whom $P$. aeruginosa had been isolated intermittently or continuously for at least six months. ${ }^{34}$ In that study we found that most patients with cystic fibrosis (37 of 52) from whom $P$. aeruginosa had not been isolated had antibody titres within the range of control titres. We found a group of patients with cystic fibrosis, however, with antibody titres greater than control values but from whom $P$. aeruginosa had not yet been isolated. These patients were suspected of having early $P$. aeruginosa infection. In this paper we present data on serum anti-pseudomonal IgG titres in a prospective study on all patients from whom $P$. aeruginosa was isolated for the first time during a study period of 18 months.

\section{Patients and methods}

Patients. The patients attended the paediatric and adult cystic fibrosis clinics at our hospital. Their age range was 3-27 years (mean (SE) 11.8 (6.7) years). There were 14 girls and three boys. All had characteristic clinical features of the disease and had had at least one positive sweat test. ${ }^{5}$ Analysis of previous results of bacteriological tests on these patients showed that $P$. aeruginosa had never been isolated from the respiratory tract, but the organism was isolated for the first time during the study.

Overall clinical state was assessed by the Shwachman score. ${ }^{6}$ A maximum of 25 points was awarded for each of the following: chest $x$ ray film, nutrition, general activity, and physical examination. Declining scores indicated a worsening condition. Chest 
$x$ ray films were assessed by the Chrispin-Norman $x$ ray score. ${ }^{7}$ The possible scores were $0-38$, an increasing score indicating an increasing abnormality.

\section{Methods}

\section{Serum}

At least two samples were available from 16 of the patients, the other patient having one sample available. Control serum samples were collected from 17 patients who attended the paediatric clinic and from whom blood specimens were taken surplus to requirements. The mean (SD) age for the control group was $9.54(1.42)$ years. None had any evidence of infection caused by $P$. aeruginosa. All samples were stored at $-20^{\circ} \mathrm{C}$ until immediately before use.

\section{Enzyme linked immunosorbent assay (ELISA)}

IgG antibodies to $P$. aeruginosa cell surface antigens were measured by ELISA as previously described. ${ }^{34}$ Seven strains of $P$. aeruginosa with serotypes $1,3,6,9,10$, and 11 and a strain that could not be typed were used. ${ }^{8}$ These serotypes comprise most isolates $(86 \%)$ from all our patients with cystic fibrosis and the serotypes of all isolates obtained from patients included in this study.

\section{Results}

During a study period of 18 months $P$. aeruginosa was isolated for the first time from 17 patients with cystic fibrosis. The serum IgG titres against $P$. aeruginosa were measured in these patients (Tables 1 and 2). The IgG titres were between 320 and 804 in 11 of the patients before the first isolation of $P$. aeruginosa from the respiratory tract and between 440 and 660 in four at the time of the initial isolation of that organism. Previous work in our laboratory has established that titres in paediatric patients without cystic fibrosis with no known $P$. aeruginosa infection were between 140 and 250, with an upper limit (99.9\% confidence limits) of $270 .{ }^{3}{ }^{4}$ In these 15 patients with cystic fibrosis, therefore, the titres were greater than the normal range of control values before or at the time of the first isolation of $P$. aeruginosa from the respiratory tract. The earliest increase in titre was 18 months before the first isolation of that organism in one patient, but in most patients the interval was between one and 10 months. There was no correlation between titre and duration before isolation of $P$. aeruginosa.

The serum IgG titres were within the normal range during the months preceding the first isolation of $P$. aeruginosa in two of the patients (Table 2). Within one month of the first isolation, however, the titre had increased to greater than control values in both patients.

Further, intermittent, isolations of $P$. aeruginosa were obtained from all 17 patients. Ten (cases 1-10) received one or two courses of intravenous antipseudomonal treatment within six months of the first isolation of $P$. aeruginosa (Table 1). Intravenous treatment was followed by a partial decline in titre in five patients (cases $1-5$ ), but $P$. aeruginosa was not eradicated from their sputum. In

Table 1 Serum IgG titre to Pseudomonas aeruginosa in patients with cystic fibrosis before and after the first isolation from the respiratory tract. Figures in parentheses are time in months after isolation or treatment, as applicable

\begin{tabular}{|c|c|c|c|c|c|c|c|c|c|c|}
\hline \multirow[t]{2}{*}{$\begin{array}{l}\text { Case } \\
\text { No }\end{array}$} & \multirow[t]{2}{*}{$\begin{array}{l}\text { Age } \\
\text { (years) }\end{array}$} & \multirow[t]{2}{*}{ Sex } & \multicolumn{2}{|c|}{$\begin{array}{l}\text { Before P. aeruginosa } \\
\text { isolation }\end{array}$} & \multicolumn{2}{|c|}{$\begin{array}{l}\text { At first } P \text {. acrugnosa } \\
\text { isolation }\end{array}$} & \multicolumn{2}{|c|}{$\begin{array}{l}\text { After } P . \text { aeruginosa } \\
\text { isolation }\end{array}$} & \multirow{2}{*}{$\begin{array}{l}\text { P. acruginosa } \\
\text { isolation after } \\
\text { treatment }\end{array}$} & \multirow[t]{2}{*}{ Treatment } \\
\hline & & & $\begin{array}{l}\text { Months before } \\
\text { first isolation }\end{array}$ & $\begin{array}{l}\text { Serum } \\
\lg G \text { titre }\end{array}$ & $\begin{array}{l}\text { Shwachman } \\
\text { score }\end{array}$ & $F E V_{l}$ & $\begin{array}{l}\text { Serum } \lg G \\
\text { titre }\end{array}$ & $\begin{array}{l}\text { Serum } \operatorname{Ig} G \text { titre } \\
\text { after treatment }\end{array}$ & & \\
\hline 1 & 14 & $\mathrm{~F}$ & $\begin{array}{r}11 \\
1\end{array}$ & $\begin{array}{l}317 \\
527\end{array}$ & 90 & 98 & $713(0 \cdot 5)$ & $420(5)$ & Intermittent & C. F \\
\hline 2 & 12 & $\mathbf{F}$ & 5 & 390 & 90 & 94 & $1074(1)$ & $420(7)$ & Intermittent & C. P. T, F \\
\hline 4 & 22 & $\mathbf{F}$ & 1 & 324 & 6) & 74 & & $274(3 \cdot 5)$ & Intermittent & T. A. F \\
\hline 5 & 11 & $\mathrm{~F}$ & 0 & 590 & 75 & 33 & & $512(0.5)$ & Intermittent & T. A. F \\
\hline 6 & 3 & $\mathrm{~F}$ & 2 & 490 & 80 & $145^{*}$ & & $<140)(10)$ & None (8) & T. $P$ \\
\hline 7 & 27 & $\mathrm{~F}$ & 2 & 580 & 70 & 50 & & $<210(5 \cdot 5)$ & None (3) & T. A \\
\hline 8 & 9 & $F$ & 18 & 450 & 90 & 74 & & $170)(1)$ & None (3) & T. P. F \\
\hline 9 & 15 & $\mathbf{M}$ & 16 & 320 & 85 & 76 & $340(1)$ & $\begin{array}{ll}190 & (0) \\
140 & (12)\end{array}$ & None (1) & $\mathrm{T}, \mathrm{A}, \mathrm{C}$ \\
\hline 10 & 3 & $\mathrm{~F}$ & 9 & 470 & 80 & 115 & & $\begin{array}{l}190(5) \\
140(8)\end{array}$ & None (18) & T. P \\
\hline
\end{tabular}

Serum $\operatorname{IgC}$ titre refers to the sum titre to seven strains, with serotype $1,3,6,9,10$, and 11 and a strain that could not be typed. C=Ceftazidime: $P=$ pipercillin; $T=$ tobramycin; $A=$ azlocillin; $F=$ flucloxacillin.

FEV $_{1}=$ Forced expiratory volume in one second as $\%$ of value predicted for height.

*Peak expiratory flow rate as \% predicted for height as patient too young for measurement of FEV 
Table 2 Serum $\operatorname{IgG}$ titre to $\mathrm{P}$. aeruginosa in patients with cystic fibrosis before and after the first isolation from the respiratory tract

\begin{tabular}{|c|c|c|c|c|c|c|c|c|}
\hline \multirow[t]{2}{*}{$\begin{array}{l}\text { Case } \\
\text { No }\end{array}$} & \multirow[t]{2}{*}{$\begin{array}{l}\text { Age } \\
\text { (years) }\end{array}$} & \multirow[t]{2}{*}{ Sex } & \multicolumn{2}{|c|}{$\begin{array}{l}\text { Before P. aeruginosa } \\
\text { isolation }\end{array}$} & \multicolumn{2}{|c|}{$\begin{array}{l}\text { At first } \mathrm{P} \text {. aeruginosa } \\
\text { isolation }\end{array}$} & \multicolumn{2}{|c|}{$\begin{array}{l}\text { After first } \mathrm{P} \text {. aeruginosa } \\
\text { isolation }\end{array}$} \\
\hline & & & $\begin{array}{l}\text { Months before } \\
\text { isolation }\end{array}$ & $\begin{array}{l}\text { Serum } \\
\text { IgG titre }\end{array}$ & $\begin{array}{l}\text { Shwachman } \\
\text { score }\end{array}$ & $F E V_{l}$ & $\begin{array}{l}\text { Months after } \\
\text { first isolation }\end{array}$ & $\begin{array}{l}\text { Serum } \\
\text { IgG titre }\end{array}$ \\
\hline 11 & 14 & $\mathbf{M}$ & () & 450 & 75 & 59 & 1 & 1020 \\
\hline 12 & 10 & $\mathrm{~F}$ & () & 410 & 80 & 75 & $17 \cdot 5$ & $7(0)$ \\
\hline 13 & 13 & $\mathrm{~F}$ & 0 & 660 & 70 & 76 & No sample & \\
\hline 14 & 5 & $\mathbf{M}$ & 10 & 804 & 90 & 6() & 1 & $150 \div$ \\
\hline 15 & 4 & $M$ & $\begin{array}{l}6 \\
3\end{array}$ & $\begin{array}{l}336 \\
385\end{array}$ & 90 & $100^{*}$ & $\frac{2}{7}$ & $\begin{array}{r}160 \% \\
\leqslant 140\end{array}$ \\
\hline 16 & 9 & $\mathrm{~F}$ & $\begin{array}{l}15 \\
7 \\
0.5\end{array}$ & $\begin{array}{l}\leqslant 140 \\
\leqslant 140 \\
\leqslant 140\end{array}$ & 80 & 118 & 1 & 410 \\
\hline 17 & 7 & $\mathbf{F}$ & 11 & 160 & 90 & 70 & $\begin{array}{r}8 \\
17\end{array}$ & $\begin{array}{l}300 \\
720\end{array}$ \\
\hline
\end{tabular}

Serum IgG titre refers to the sum titre to seven strains, with serotypes $1,3,6,9,10$, and 11 and a strain that could not be typed.

$\mathrm{FEV}_{1}=$ Forced expiratory volume in one second as \% of value predicted for height

* Peak expiratory flow rate as \% predicted for height as patient too young for measurement of FEV

$\dagger$ Patients treated with continuous hydrocortisone.

the other five patients (cases 6-10) the titre decreased to within the control range in the months after intravenous treatment, and no further isolations of $P$. aeruginosa were obtained from their respiratory tract.

Four patients (cases 11,12,16, and 17) were not given intravenous treatment. $P$. aeruginosa was isolated intermittently from their sputum, and subsequent serum samples from all four patients showed an increase in IgG titre.

During the study, two patients (cases 14 and 15) began continuous treatment with corticosteroids. The IgG titre, which had been greater than normal, decreased to the lower level of detection within two months of beginning treatment with steroids. It remained at this low value for the next eight to 15 months, despite occasional isolations of $P$. aeruginosa from their sputum.

No further serum sample was available from one patient (case 13), although $P$. aeruginosa was isolated intermittently from sputum samples.

There was no significant correlation between the IgG titre of the entire group of patients described in this study with either the Shwachman score or the Chrispin-Norman $x$ ray score, with the notable exception of case 3 , in whom a severe infection was rapidly established.

\section{Discussion}

The results presented in this paper show that every patient with cystic fibrosis from whom $P$. aeruginosa had never been isolated but who had a serum IgG titre against $P$. aeruginosa greater than the control range subsequently had that organism isolated intermittently from the respiratory tract. In 11 of the 17 patients the serum IgG titre was greater than control values one to 18 months before the first isolation of that organism. A further four patients had significantly raised IgG titres at the time of the first isolation of $P$. aeruginosa. The presence of serum antibodies specific for $P$. aeruginosa in these patients suggests infection by that organism for some months before its isolation in significant numbers from the respiratory tract. Bacteriological examination of these patients often had to be based on throat swabs; but even if sputum is produced, organisms present in numbers less than $10^{7}$ per litre are unlikely to be detected or considered significant by the semi-quantitative methods used in our laboratory. In addition, treatment with nebulised antibiotics may eliminate organisms from sputum samples but not necessarily all those present in the lungs.

The contribution of cross reacting antibodies to other Gram negative bacteria to this assay has been shown to be negligible. ${ }^{3}$ This finding is in agreement with that of Kohler et al: in a radioimmunoassay using rabbit anti-pseudomonal serum to detect pseudomonal cells in urine, cross reaction with other Gram negative bacteria was also shown to be low. ${ }^{9}$ We have previously shown that antibodies reacting with $P$. aeruginosa were present in very low numbers in patients without cystic fibrosis with no $P$. aeruginosa infection (between 140 and 250, with an upper limit $(99.9 \%$ confidence limits) of 270$) .{ }^{34}$ This is also in agreement with the findings of other workers. Hoiby, using counterimmunoelectrophoresis and a sonicated antigen, showed that the prevalence of precipitating antibodies against $P$. aeruginosa increased gradually with age in a normal 
population. ${ }^{10-12}$ The antibodies were present, only at low titres, however, in the normal population and were directed against two antigens that cross reacted with antigens from other bacterial species. ${ }^{10-12}$ Cost $e t a l$, in a survey of 100 adults of unspecified age with no known $P$. aeruginosa infection, using ELISA, showed that serum antibodies against $P$. aeruginosa surface antigens were also present at low titres. ${ }^{13}$

Two of the patients in this study had titres within the control range before the first isolation of $P$. aeruginosa. Within about four weeks, however, the titre of both patients had increased to above control values. Given the delay in response by the humoral immune system, it would seem that $P$. aeruginosa was first isolated at an early stage of pseudomonal infection in these two patients.

Subsequent serum samples, available from seven patients, after the beginning of intermittent $P$. aeruginosa isolation but before intravenous antipseudomonal treatment, all showed further increases in titre. This increase suggests a continued antigen presence and further antigenic stimulus.

Ten of these 17 patients received intravenous antipseudomonal treatment. $P$. aeruginosa was not eradicated from the sputum of five patients, and although their IgG titres decreased, they were still greater than control values. In the other five patients intravenous treatment was followed by a decline in titres to within the control range, accompanied by no further isolations of $P$. aeruginosa from the respiratory tract, for between three and 18 months to date. This is in contrast with the effect of treatment on chronic $P$. aeruginosa infection, when long term eradication of the organism after treatment is an extremely rare occurrence. ${ }^{12}$

The lack of correlation between the IgG titre of the entire group of patients described in this study with either the Shwachman score or the ChrispinNorman $x$ ray score is perhaps not surprising for several reasons. Both scores are fairly crude measures of clinical state: the infection by $P$. aeruginosa in these patients was in the very earliest stages and so was unlikely to affect either of these scores. Furthermore, some of these patients had a well established Staphylococcus aureus or other bacterial infection, which will mask the small effects of the beginning of an infection by $P$. aeruginosa.

The antigen used in this assay was washed, intact cells being treated with glutaraldehyde. Antigens accessible for antibody binding are, therefore, lipopolysaccharides and those cell membrane proteins that are exposed to the surface, with glutaraldehyde forming crosslinks between amino groups. ${ }^{17} 18$ The strain that could not be typed used in this assay often produced a significant titre, which may be due to antibodies directed against the core region of lipopolysaccharide, the cell membrane proteins, or other cell surface antigens. Although the cell membrane proteins are well conserved, they are present in different amounts in different strains. ${ }^{1920}$ A number of workers have reported serum antibodies to surface components other than the lipopolysaccharide side chain: antibodies specific to the core region of lipopolysaccharide were detected in the serum of $74 \%$ of patients with cystic fibrosis chronically infected with $P$. aeruginosa $a^{21}$ and in rabbit immune serum. ${ }^{22}$ Serum antibodies to outer membrane proteins have been shown in experimentally infected mice ${ }^{2324}$ and patients with cystic fibrosis chronically infected with $P$. aeruginosa. ${ }^{21} 25$

We have previously reported that this assay was a sensitive and specific measure of pulmonary infection by $P$. aeruginosa in patients with cystic fibrosis intermittently or chronically infected for at least six months. The immunological changes correlated with both the severity of infection and the clinical state of the patient. ${ }^{34}$ Hoiby et al, using crossed immunoelectrophoresis and a sonicated preparation of $P$. aeruginosa, showed an increased number of serum precipitins against $P$. aeruginosa in patients infected for at least six months, and increased numbers of precipitins correlated with a worsening clinical state. ${ }^{14-16}$ No such increase was detectable in patients infected for less than six months. ${ }^{14-16}$ The results presented here show that the humoral response to pseudomonal infection can now be monitored during the first months of pseudomonal infection, as well as in the later stages, by ELISA.

We thank the Cystic Fibrosis Research Trust, United Kingdom, for their research grant No 244, which made this work possible.

\section{References}

1 Pier GB. Pulmonary discase associated with Pseudomonas acruginosa in cystic fibrosis: current status of the host-bacterium interaction. J Infect Dis 1985;151:575-80.

2 Mearns MB. Hunt GH, Rushworth R. Bacterial flora of respiratory tract in patients with cystic fibrosis, 1950-1971. Arch Dis Child 1972;47:902-7.

${ }^{3}$ Brett MM, Ghoncim ATM. Littlewood JM. Losowsky MS Development of enzyme linked immunosorbent assay (ELISA) to detect antibodies to $P$. acruginosa cell surface antigens in sera of cystic fibrosis patients. J Clin Pathol 1986;39:1124-9.

4 Brett MM, Ghoneim ATM, Littlewood JM. Serum antibodies to Pseudomonas aeruginosa in cystic fibrosis. Arch Dis Child 1986;61:1114-20.

5 Gibson LE, Cooke RE. A test for concentration of electrolytes in sweat in cystic fibrosis of the pancreas utilizing pilocarpine iontophoresis. Pediatrics 1959;23:545-9.

6 Shwachman H. Kulczycki LK. Long term study of one hundred and five patients with cystic fibrosis. Am J Dis Child 1958;96: $6-15$. 
${ }^{7}$ Chrispin AR, Norman AP. The systematic evaluation of the chest radiograph in cystic fibrosis. Pediatr Radiol 1974;2:101-6.

${ }^{8}$ Liu PV, Matsumoto H, Kusama H, Bergen T. Survey of heat-stable, major somatic antigens of Pseudomonas aeruginosa. International Journal of Systematic Bacteriology 1983;33:256-64.

${ }^{9}$ Kohler RB, Wheat J, White A. Rapid diagnosis of Pseudomonas aeruginosa urinary tract infection by radioimmunoassay. J Clin Microbiol 1979;9:253-8.

10 Hoiby N. Normally occurring precipitating antibodies against Pseudomonas aeruginosa. Prevalence, specificities and titres. Scand J Immunol 1975;4(Suppl 2):197-202.

"Hoiby N. Antibodies against P. aeruginosa in serum from normal persons and patients colonised with mucoid or nonmucoid $\mathrm{P}$. aeruginosa: results obtained by crossed immunoelectrophoresis. Acta Pathol Microbiol Immunol Scand $[C]$ 1977;85:142-8.

12 Hoiby N, Wiik A. Antibacterial precipitins and autoantibodies in serum of patients with cystic fibrosis. Scand J Respir Dis 1975;56:38-46.

13 Cost KM, West CS, Brinson D, Polk HC. Measurement of human antibody activity against Escherichia coli and Pseudomonas aeruginosa using formalin treated whole organisms in an ELISA technique. $J$ Immunoassay 1985;6:23-43.

${ }^{14}$ Hoiby N. Pseudomonas aeruginosa infection in cystic fibrosis. Diagnostic and prognostic significance of $\mathrm{P}$. aeruginosa precipitins determination by means of crossed immunoelectrophoresis. Acta Pathol Microbiol Immunol Scand /Cl 1977;85(Suppl 262): $1-95$.

15 Hoiby N. Pseudomonas aeruginosa infection in cystic fibrosis. Relationship between mucoid strains of $P$. aeruginosa and the humoral immune response. Acta Pathol Microbiol Immunol Scand [B] 1974;82:551-8.

${ }^{16}$ Hoiby N, Winge Flensborg E, Beck B, Friis B, Vidar Jacobsen S, Jacobsen L. Pseudomonas aeruginosa infection in cystic fibrosis. Diagnostic and prognostic significance of $\mathrm{P}$. aeruginosa precipitins determined by means of crossed immunoelectrophoresis. Scand J Respir Dis 1977;58:65-79.
${ }^{17}$ Czerkinsky C, Rees AS, Bergmeier A, Challacombe SJ. The detection and specificity of class specific antibodies to whole bacterial cells using a solid phase radioimmunoassay. Immunology 1983;53:192-200.

18 Peters K, Richards FM. Chemical cross linking reagents and problems in studies of membrane structure. Anal Biochem 1978;46:523-51.

19 Muthiara LM, Nicas TI, Hancock REW. Outer membrane proteins of Pseudomonas aeruginosa serotype strains. J Infect Dis 1982;146:770-9.

${ }^{20}$ Hancock REW, Wieczorek AW, Mutharia LM, Poole K. Monoclonal antibodies against Pseudomonas aeruginosa outer membrane antigens:isolation and characterisation. Infect Immun 1982;37:166-71.

${ }^{21}$ Hancock REW, Mouat ECA, Speert DP. Quantitation and identification of antibodies to outer membrane proteins of Pseudomonas aeruginosa in sera of patients with cystic fibrosis. $J$ Infect Dis 1984;149:220-6.

22 Borowski RS, Stock LM, Schiller NL. Development of an enzyme-linked immunosorbent assay for studying Pseudomonas aeruginosa cell surface antigens. J Clin Microbiol 1984;19: 736-41.

${ }^{23}$ Hedstrom RC, Pavlovkis OR, Galloway DR. Antibody response of infected mice to outer membrane proteins of Pseudomonas aeruginosa. Infect Immun 1984;43:49-53.

24 Jones Danneman P, Michael JG. Reaginic antibody production to protein antigens of Escherichia coli and Pseudomonas aeruginosa by mice. Infect Immun 1976;14:694-702.

${ }^{25}$ Lam JS, Mutharia LM, Hancock REW, et al. Immunogenicity of Pseudomonas aeruginosa outer membrane antigens examined by crossed immunoelectrophoresis. Infect Immun 1983;42: 88-98.

Correspondence to Dr M M Brett, Department of Medicine, St James's University Hospital, Beckett Street, Leeds LS9 7TF, England.

Received 13 November 1986

\section{Nineteen hundred years ago}

"We trained hard-but it seemed that every time we were beginning to form up into teams, we would be re-organised. I was to learn later in life that we tend to meet any new situation by re-organising, and a wonderful method it can be for creating the illusion of progress while producing confusion, inefficiency and demoralisation."

GAIUS PETRONIUS-AD 70. 